\title{
Hazelnut breeding in the National Dendrological Park "Sofiyivka" of the NAS of Ukraine
}

\author{
I. S. Kosenko ${ }^{1^{*}}$, A. I. Opalko ${ }^{12^{*}}$, O. A. Balabak ${ }^{1}$, O. A. Opalko ${ }^{1}$, A. V. Balabak ${ }^{2}$ \\ ${ }^{1}$ National Dendrological Park "Sofiyivka" of the NAS of Ukraine, 12a Kyivska Str., Uman, Cherkasy region, 20300, Ukraine, \\ "e-mail: ndp.sofievka@gmail.com \\ 2Uman National University of Horticulture, 1 Instytutska Str., Uman, Cherkasy region, 20300,Ukraine, *e-mail: opalko_a@ukr.net
}

\begin{abstract}
Purpose. To evaluate hazelnut cultivars, species and hybrids from the genetic collection of Corylus spp. in the National Dendrological Park "Sofiyivka" of the NAS of Ukraine for the complex of economic characters. An attempt has been made to analyze the information on Corylus spp. identity, taxonomy and description, dissemination and ecological requirements of the species, possibilities to use the genetic potential for developing new cultivars. Methods. The value of the Corylus spp. collection representatives was investigated using conventional testing procedures. For summarizing information concerning phylogenetic reconstruction of the Corylus L. genus and hazelnut, a number of scientific publications to be proposed for discussion was analyzed. The oil content in hazelnut kernels and the fatty acid composition was determined using official methods. Results. The best samples of hazelnut genetic collection were included into the broad hybridization programme, and C. chinensis Franch. representatives as well. A number of hybrid seedlings was obtained including new hazelnut cultivars 'Sofiyivsky 1', 'Sofiyivsky 2' and 'Sofiyivsky 15' which were characterized by spherical or almost spherical fruits, high winter hardiness and drought resistance, as well as the absence of rhythmicity in fruiting. Conclusions. The collection of varieties, forms, cultivars and species of the Corylus L. genus created during the last years can be the base for hazelnut breeding in Ukraine.
\end{abstract}

Keywords: breeding, cultivar, natural area of genus, hybridization programme, nut, species.

\section{Introduction}

As the intensive fruit-growing develops the hazel (Corylus spp.) cultivated forms under the name of hazelnut, also known as filbert (C. domestica Kos. et Opal.), gain in importance as nuciferous fruit culture in Ukraine. Though, hazelnut takes the honorable second place conceding to almond (Prunus dulcis (Mill.) D.A. Webb.), on the nut world market, demand for hazelnut in Ukraine is provided with the own yield for $12-15 \%$ only, because of the deficient cultivation of it. The rest of needs are held with the help of import which cause the rise in the cost of the nuts and products of their processing [1]. At the beginning of the 21st century average indices of world hazelnut (in shell) production exceeded 900 thousand tons with fluctuations over the years in the range of 616-1071 thousand tons. In this amount Turkey has $70-75 \%$ with an annual production

Ivan Kosenko

https://orcid.org/0000-0003-2085-7477

Anatolii Opalko

https://orcid.org/0000-0003-0664-378X

Oleksandr Balabak

https://orcid.org/0000-0002-7435-9783

Olga Opalko

https://orcid.org/0000-0003-3081-0648

Alla Balabak

https://orcid.org/0000-0002-7483-277X of 450-800 thousand tons of unshelled nuts. Italy takes the second place with the index of 100-130 thousand tons, the third and fourth places are divided by the USA and Azerbaijan, with the annual production 20-35 thousand tons. Then, Georgia - 25-30, China and Iran at 18-25, then Spain, which in last years have reduced production to 12-17 thousand tons [2]. Now in the world market there is an increase in demand for hazelnut products, which makes its production more profitable. Among the potential buyers of large quantities of nuts, Italy, Germany and Scandinavia are the largest. Thanks to the development of hazelnut culture in Turkey, where over 400 thousand hectares are used for hazelnuts, almost 250 thousand Turkish families are living on its cultivation today and about 8 million jobs are provided by the production, processing and export of nuts.

Turkish hazel dendroid (C. colurna L.) and a number of cultivars and forms of C. maxima Mill. are widely used in the urban park movement, while the rest of Corylus species are still maintained mainly in the collections of botanical gardens, dendrological parks and arboretums. However, cultivation experience of many valuable forms of North American and East Asian species, valuable in decorative qualities indicates the great prospects of representatives of the genus Corylus introduction into decorative gardening. Due to the stability of hazel to adverse environmental factors, many 
of its species, as well as hazelnut cultivars and forms can be successfully used to strengthen the slopes and in various protective plantations [1].

Observation of various Corylus spp. healing power which has been used in folk medicine since prehistoric times, gradually finds its followers in scientific pharmacological circles. Outlook valuation of the nut oil as a raw material for obtaining the new types of immunoprophylactic drugs deserve attention as well as the tests of vaso-constrictive effects of hazel leaves extracts on laboratory animals [3], antioxidant effects and cytotoxic activity of nut cell membranes extracts on human cancer [4], etc. Creation of medicines based on the species-specific and protective antigens included into the liposomes is considered as one of the promising directions in developing methods of effective protection from the most dangerous infections [5]. Lecithins (esters of choline amino-alcohol and diglyceride phosphoric acids), which are an important representatives of essential (irreplaceable) phospholipids, produced from organisms and tissues of mammals (dorsal and brain of cattle and pigs), chicken eggs, fish, mollusks [6] are used. Essential phospholipids are contained in unrefined vegetable oil of soy (Glycine $\max$ (L.) Merr.), sunflower (Helianthus annuus L.), walnut (Juglans regia L.), hazel (Corylus spp.), etc. At the same time, phospholipid's average content in nuts Juglans regia was $0.3-0.4$, whereas in nuts Corylus spp. their number reached $0.5-0.9 \%$ [7]; it founds the grounds of successful selection on this feature. In addition, hazelnut lecithin can act both as a biologically active additive to food and feed, and as a raw material for the creation of liposomal nanoemulsions and nanodispersions for food products and additives, as well as for the creation of liposomal drugs.

The research purpose consists of estimation of hazelnut cultivars, species and hybrids from the genetic collection of Corylus spp. in the National dendrological park "Sofiyivka" of NAS of Ukraine according to the complex of economic and valuable features. We also attempt to discuss the currently available information on Corylus spp. identity, taxonomy and description, distribution and ecological requirements of the species, possibilities of exploitation of genetic potentiality for developing new cultivars.

\section{Materials and methods}

Genetic collection of Corylus spp. in the National Dendrological Park "Sofiyivka" of NAS of Ukraine counts more than 200 samples, be- longing to 11 botanical species, acknowledged in different lists of leading world botanical establishments $[8,9]$. Including more than 90 cultivars of domestic and foreign breeding and over 50 hybrid seedlings of own breeding, tested in the links of collection and hybrid garden, as well as in the garden of preliminary cultivar testing [1].

In the somatic cells of the genus Corylus representatives, chromosomes diploid number is $2 n=22$, as well as in the cells of species studied by cytologists before; however, there are some reports about other chromosomal numbers of individual representatives of this genus presented in the literature [1]. The question is, foremost, about Robert Woodworth publication [10], who counted on 14-chromosomes during the research of meiotic preparations of C. americana Walter, C colurna, C. cornuta, C. heterophylla var. sutchuensis Franch., C. pontica $\mathrm{K}$. Koch (it is now considered as the synonym of C. avellana var. pontica (K. Koch) H.J.P. Winkl.), C. sieboldiana Blume and C. vilmorinii Rehd., that confirmed $2 n=28$. This repeatedly quoted article had been published in 1929 in the authoritative botanical magazine "Botanical Gazette" [11-14] caused long-term uncertainty as for the chromosomes diploid number of the Corylus species have been mentioned above. Thus, some authors limited the statement of possible $2 n=28$ equally with normative $2 n=22$ [11, 12], had been cited R. Woodworth. Another stated the necessity of experimental confirmation of calculations for $2 n=28$ [15], while Veli Erdogan [16] considered Woodworth determinations as the mistaken one, because of the wrong interpretation of meiotic preparations. Calculation error could arise up because of the application of imperfect methodology by cytological researches, realization of that is laboured by small size of Corylus spp. chromosomes. Therefore, nowadays $2 n=2 x=22$ is considered to be an avowed standard for Corylus spp. [1, 16-19] with the exception of individual cases of chromosomal aberrations and polyploidy $[16,20]$. Nearly all the representatives of Corylus are diploids, however, Roberto Botta with coauthors (1986) reported about spontaneous tetraploid of $C$. heterophylla Fisch. ex Trautv. [16]. Among the other examples of unusual chromosomes number we should mention the aneuploidies from $2 n=18$ in somatic tissues of C. colurna and C. maxima f. atropurpurea (Dochnahl) H.J.P. Winkl. [14, 16], so as the tetraploids and spontaneous triploid seedlings of C. avellana L. induced with the colchicine treatment $[12,16]$. Based on N. I. Vavilov ideas have been concerning the work of plant 
genetic resources [21], the goals and objectives of our studies were determined. They included Corylus spp. have been growing in the park and its environs certification, their systematization, maintenance and collection expansion, including the development and improvement of breeding methods, as well as the study of their breeding value. The first expeditions were conducted in the localities of Corylus spp. in Ukraine, the Caucasus and Central Asia, as well as in China and a number of European countries, which significantly increased the species and cultivar and forms collection of hazelnut and hazel, the best representatives of which were involved in to the breeding process.

Selection and isolation of branches with female flowers, inter-cultivar hybridization, and hazelnut cultivars crossing with the help of selected representatives of $C$. chinensis Franch., C. colurna, C. maxima and other species were carried out during the male inflorescences (before pollination) spring growth. Pollen for crossing was collected from cut branches with catkins, the development of which was awakened in room conditions. Cut branches put in a vessel with water on a large sheet of paper, leaving them overnight in a cool dry $\left(15-16^{\circ} \mathrm{C}\right)$ room. Branches with catkins of the same cultivar were placed in the room, at the same time, to prevent pollen contamination and were left to its rash. Pollination was carried out without removing the insulators, had been untangling only the upper part of the insulator-sleeve and tying it again after pollination or without decoupling, blowing the pollen into the insulator with insufflator MO-03 Pollination had been repeated in 2-3 days. Tight linen FPP-15 (Petrianov filter linen) or parchment paper was used for bagging. Likewise the seedlings obtained from seeds formed from the best cultivars free pollination were used [1].

The oil content in hazelnut kernels was determined by the official method (AOAC, Official Method of Analysis ...: Fatty Acids (Free) in Crude ..., 2000). To analyze the fatty acid composition (the number of saturated and unsaturated fatty acids), a gas chromatography method with a flame ionization detector was used in accordance with GOST 30418-96 "Vegetable oils. Method for determination of the fatty acid composition" [22].

\section{Results and discussion}

Assessment results of the collection of hazelnut cultivars of domestic and foreign breeding up to the combination of economic and valuable feature showed the advantages of such cultivars as 'Dokhidnyi', 'Funduk-85' and 'Bol- hradska novynka'. These cultivars increased the yield of nuts 4.5-6.4 times (from 61.6 -179.2 to $394.8-809.2 \mathrm{~kg} / \mathrm{ha}$ ), with a rather high content $(68.7-75.8 \%)$ of the oil in the cores during the first three years after the introduction into the fruiting period. In addition to the cultivars mentioned above, the early event of fruiting interstice was relevant for such cultivars as 'Dar Pavlenka', 'Zorinskiy', 'Ziuidivskyi', 'Karamanovskiy', 'Stepovyi' and 'Shedevr', the productivity of which has increased by 1.7-4.5 times during the first three years. At the same time, the high-oil cultivar 'Hrandioznyi' yielded to the best yield grade cultivar 'Dokhidnyi' during the first year of fruit bearing at $171.4 \mathrm{~kg} / \mathrm{ha}$, and for the third year fell by $414.4 \mathrm{~kg} / \mathrm{ha}$ (Table).

Subject to the meteorological conditions of research years with a general tendency of specificity the oil content of hazelnut kernels slightlyvaried. Suchcultivarsas 'Urozhainyi-80', 'Funduk-85' and 'Hrandioznyi' with average indexes $74.5 ; 74.3 \%$ and $74.2 \%$ exposed to be the best as for the oil content. Almost all studied cultivars should be attributed to the group of high-oil, excepting the cultivars 'Lozivskyi urozhainyi' and 'Dar Pavlenka'.

Taking into account the results of the assessment, as well as data from previous studies [1], the parameters of breeding task for hazelnut were determined: potential yield - $3.5 \mathrm{t} / \mathrm{ha}$; weight of nut $-3,0-3,5 \mathrm{~g}$; kernel outlet is not less than $50 \%$ from the total mass of the fruit; shell thickness - no more than $1.0 \mathrm{~mm}$; the number of fruits in the collective fruit - more than 4 pcs. The pollinating ability was also evaluated, paying attention to samples that formed large catkins with a large amount of pollen and with corresponding sets of $S$-genes that did not block reciprocal pollination, the use of which made it possible to reduce the number of pollinating plants on the plantation [1]. Pollinators were selected without the undesirable effects of xenia; particularly relatively the scales of the pellicle on the kernel, which is usually formed from the fertilization with pollen of C. colurna and reduce the nuts quality [1, 23]. In addition to cross-breeding crossings, the representatives from the collection of the NDP "Sofiyivka" were included. They were $C$. chinensis, C. avellana, C. cornuta, C. heterophylla, C. maxima and other species.

During the observations of hybrid seedlings growing methods, the efficiency of early autumn seedlings with the help of collective fruits had been confirmed (that is, nuts unrefined from cupule), which provided about $100 \%$ germination, while had been remaining the least labo- 
Table

Hazelnut cultivars yield during the first three years after the introduction into the fruiting period, $\mathrm{kg} / \mathrm{ha}$

\begin{tabular}{|c|c|c|c|c|}
\hline \multirow{2}{*}{ Cultivar } & \multicolumn{3}{|c|}{ Yield year } & \multirow{2}{*}{$\begin{array}{l}\text { Total yield during } \\
\text { the first three years }\end{array}$} \\
\hline & 2012 & 2013 & 2014 & \\
\hline 'Dokhidnyi' & 179.2 & 355.6 & 809.2 & 1344.0 \\
\hline 'Ziuidivskyi' & 114.8 & 392.0 & 638.4 & 1030.4 \\
\hline ‘Funduk-85' & 140.0 & 338.8 & 456.4 & 935.2 \\
\hline 'Zorinskiy' & 64.4 & 254.8 & 509.6 & 828.8 \\
\hline 'Stepovyi' & 86.8 & 266.0 & 470.4 & 823.2 \\
\hline 'Shedevr' & 86.8 & 263.2 & 459.2 & 809.2 \\
\hline ‘Dar Pavlenka' & 95.2 & 226.8 & 380.8 & 702.8 \\
\hline ‘Bolhradska novynka' & 61.6 & 229.6 & 394.8 & 686.0 \\
\hline ‘Lozivskyi urozhainyi’ & 16.8 & 98.0 & 518.0 & 632.8 \\
\hline 'Morozivskyi' & 19.6 & 117.6 & 467.6 & 604.8 \\
\hline ‘Karamanovskiy' & 53.2 & 176.4 & 355.6 & 585.2 \\
\hline 'Koronchatyi' & 5.6 & 86.8 & 462.0 & 554.4 \\
\hline 'Hrandioznyi' & 7.8 & 117.6 & 257.6 & 383.0 \\
\hline 'Urozhainyi-80’ & 5.6 & 100.8 & 271.6 & 378.0 \\
\hline $\mathrm{LSD}_{0,05}$ & 3.6 & 11.6 & 24.8 & - \\
\hline
\end{tabular}

rious [24]. Derived seedlings $F_{1}$ were grown in containers under controlled conditions of vegetative construction with fine-dispersed moistening, and were transplanted to grow and evaluate in the hybrid garden-producing section of the NDP "Sofiyivka" of NAS of Ukraine, where they carried out a comprehensive assessment of both seedlings and nuts according to generally accepted methods [1].

The best seedlings were propagated according to the technology developed by us as a result of a comparative evaluation of various methods of hazelnut reproduction, taking into account the use of growth stimulants, different timing and methods of harvesting the cuttings material [25].

The number of hazelnuts cultivar patterns the best of which were prepared for submission to the State Veterinary and Phytosanitary Service of Ukraine (a modern analogue of the State Variety Test Commission) for testing, including the cultivars 'Sofiyivsky 1' ('Ukraina-50' $\times$ C. avellana 'Fuscorubra'), 'Sofiyivsky 2' ('Dar Pavlenka' $\times$ C. avellana 'Fuscorubra'), 'Sofiyivsky 3' ('Cherkeskyi-2' $\times$ C. chinensis), 'Sofiyivsky 4' ('Shedevr' $\times$ C. avellana 'Fuscorubra') and 'Sofiyivsky 15' ('Garibaldi' $\times$ C. chinensis). These cultivars are characterized by spherical or almost spherical fruits ('Sofiyivsky 3', 'Sofiyivsky 15'), raised winter hardiness and drought resistance, as well as the lack of periodicity of fruiting in comparison to the Turkish and Azeri cultivars.

Such cultivars as 'Garibaldi', 'Dar Pavlenka', 'Ukraina-50', 'Cherkeskyi-2', and 'Shedevr' which were used as the maternal plant had been the best in hybridization; whereas $C$. avellana 'Fuscorubra' and $C$. chinensis were the best pollinators. Findings concerning C. chinensis in hybridization with hazelnut cultivars used as the maternal plants, somewhat contradict the literature data of successful hybridization of C. chinensis $\times C$. avellana so as incompatibility in reciprocal crossing. This discrepancy between the results of crosses can be explained by the limited number of C. avellana genotypes in the cited experiments [23] and/or by the fact that the samples of $C$. chinensis were introduced not from the initial natural area, but from the collection of Berlin Botanical Garden (Botanischer Garten Berlin-Dahlem) where they had been imported from the natural area (China). We should suppose that seed populations of C. chinensis were subjected to the action of natural selection in the conditions of Berlin-Dalem, and then in Uman, which influenced the fertilizing ability of the pollen.

The oil content in the studied samples ranged from $61.4 \%$ to $65.1 \%$ of the kernel mass. Under suitable conditions and with this amount of oil in hazelnut kernels, it is possible to obtain approximately $1000 \mathrm{~kg}$ of oil per hectare, which is very advantageous in comparison with the amount of soybean oil produced ( 500 $\mathrm{kg} / \mathrm{ha}$ ). Such high oil content in hazelnut nuts makes it a promising source of plant material for potential commercial value.

It is important that each hazelnut sample characterized with the fatty acid compositions of a higher percentage (\%) of oleic C18: $1 \omega 9$ (77.8-81.0) and linoleic C18: $2 \omega 6(9,6-15,7)$ acids with a significantly lower amount of palmitic C16: 0 (5.0-5.7), stearic C18: 0 (2.4-3.6) and linoleic C18: 3 (0.07-0.14) acids (Figure).

Hazelnut kernels of such cultivars as 'Sofi- 
yivsky 2' and 'Sofiyivsky 4' showed the greatest amount of unsaturated acids. Such cultivars should be considered as the prospective as a raw material for the production of hazelnut oil and essential phospholipids for industrial cultivation, as well as for the inclusion into the hybridization to improve the hazelnut in fruit quality. At the same time, it should be noted that, according to the fatty acid composition of the oil, the hazelnuts mentioned above are not differ much. We have every reason to concede the cultivar 'Sofiyivsky 15' as the most prom-

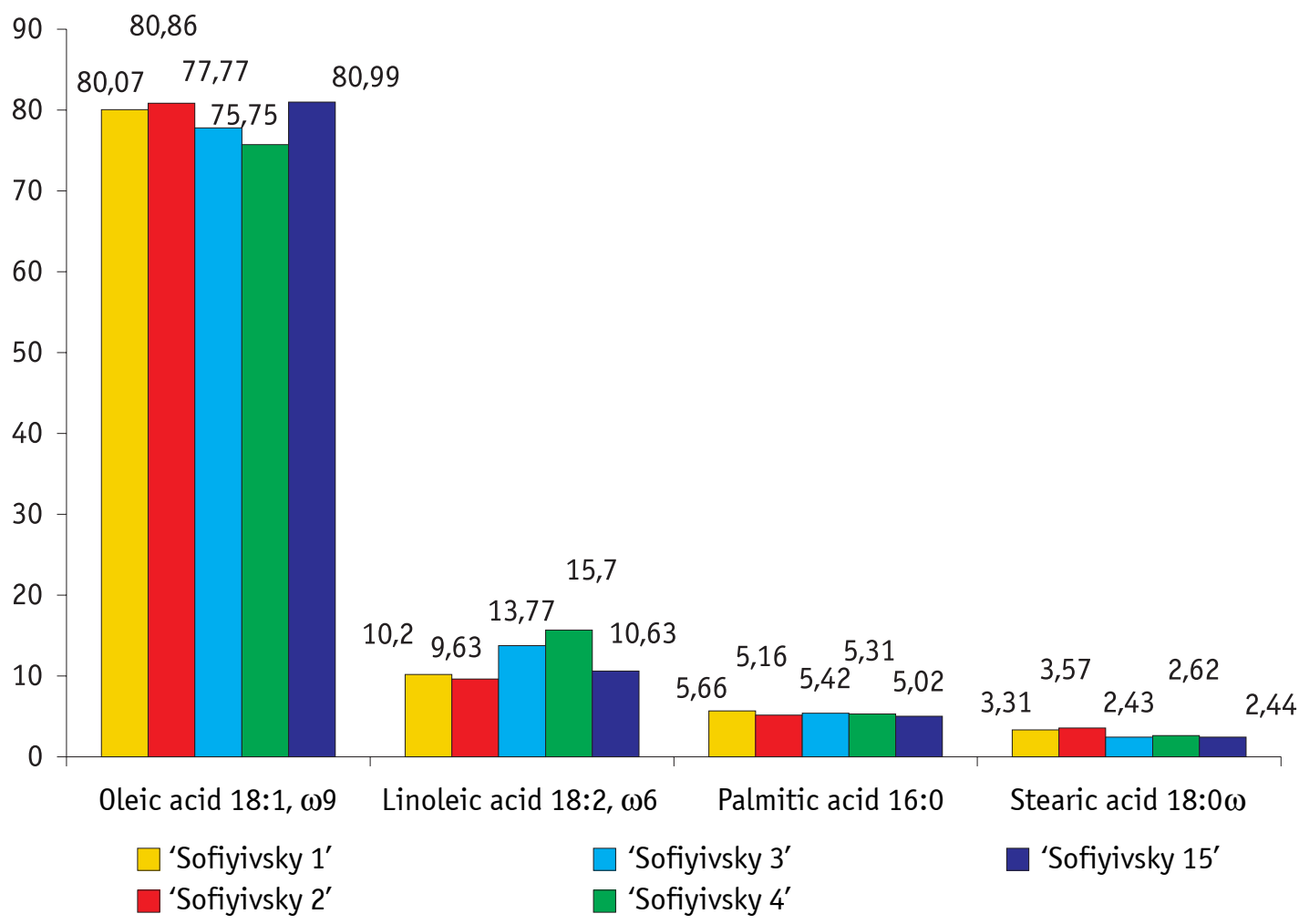

Figure. Fatty-acid oil content of the new hazelnut cultivars

ising, taking into consideration the high productivity and early-maturing, suitable for treatment almost spherical nut shape. The total content of oleic and linoleic acids in the kernels of researched hazelnuts was over $90 \%$ from the total fatty acid content in the kernels of these cultivars.

Such an amount of unsaturated fatty acids in hazelnut kernels of the new cultivars indicates the prospect of using extraordinary raw potencies of newly created cultivars with parallel further genotypes improvement, as well as the development of effective schemes of lecithin production adapted to the specific composition of hazelnut fatty acids.

\section{Conclusions}

Cultivars and species efficiency of Corylus L. collection of the National dendrological park "Sofiyivka" of NAS of Ukraine in the hybridization is confirmed by the creation of valuable breeding material where a number of applicants for the cultivar have already been selected, 'Sofiyivsky 15 ' in particular, combined super-early fruiting period introduction with a rapid yield increase. Winter and drought resistance, high oil content and the prevalence of the most valuable unsaturated fatty acids in hazelnut oil are also very important.

\section{References}

1. Kosenko, I. S., Opalko, A. I., Balabak, 0. A., \& Shulga, S. M. (2016). The use of Corylus spp. genetic collection of the National Dendrological Park "Sofiyivka" for hazelnuts Corylus domestica Kos. et Opal. breeding. Avtokhtonni ta introdukovani roslyny [Autochthonous and invasive plants],12,121-136. [in Ukrainian]

2. Hazelnuts, with shell. (2014). In FAOSTAT Domains Production/ Crops: Average. URL: http://faostat3.fao.org/browse/Q/QC/E (accessed 25.05.2017)

3. Maloshtan, L. M., Kalenichenko, G. S., \& Dorovskyy, 0. V. (2015) The study of the action of the thick extract from the leaves of Corylus avellana on the vascular tissue permeability. Klin. farm. [Clinical Pharmacy], 19(4), 26-29. doi: 10.24959/cphj.15.1362

4. Esposito, T., Sansone, F., Franceschelli, S., Del Gaudio, P., Picerno, P., Aquino, R. P., \& Mencherini, T. (2017). Hazelnut (Corylus avellana L.) shells extract: phenolic composition, antioxidant effect and cytotoxic activity on human cancer cell lines. Int. J. Mol. Sci., 18(2), 392. doi: 10.3390/ijms18020392

5. Lemmon, M. A. (2008). Membrane recognition by phospholipidbinding domains. Nat Rev Mol Cell Biol., 9(2), 99-111. doi: $10.1038 / \mathrm{nrm} 2328$ 
6. Efremenko, V. I. (1999). Liposomy (poluchenie, svoystva, aspekty primeneniya $v$ biologii $i$ meditsine) [Liposomes (obtaining, properties, aspects of usage in biology and medicine)]. Stavropol: N.p. [in Russian]

7. Angelova-Romova, M., Zlatanov, M., Antova, G., Momchilova, S., Blagoeva, E., \& Nikolova, M. (2013). Phospholipids content and composition of hazelnut and walnut cultivars grown in Bulgaria. Comptes rendus de l'Académie bulgare des Sciences, 66(12), 1689-1694.

8. Corylus. (2017). In Catalogue of Life: 29th May 2017. Naturalis Biodiversity Center. URL: http://www.catalogueoflife.org/ testcol/search/all/key/Corylus/match/1 (accessed 30.05.2017)

9. Corylus. (2013). In The Plant List by the Royal Botanic Gardens Kew and Missouri Botanical. URL: http://www.theplantlist.org/ tpl1.1/search?q=Corylus (accessed 23.08.2017).

10. Woodworth, R. H. (1929). Cytological studies in the Betulaceae. II. Corylus and Alnus. Botanical Gazette, 88(4), 383-399.

11. Fedorov, A. A. (Ed.). (1969). Khromosomnye chisla tsvetkovykh rasteniy [Chromosome numbers of flowering plants]. Leningrad: Nauka. [in Russian]

12. Danielsson-Santesson, B. (1951). Fortsatta Undersökningar av polyploid hassel. Sveriges Pom. Fören. Ersskrift., 52, 38-48.

13. Molnar, T. J., (2011) Corylus L.. In C. Kole (Ed.), Wild crop relatives: genomic and breeding resources. Forest trees. (Vol. 10, pp. 15-48). Berlin, Heidelberg: Springer. doi: 10.1007/978-3642-21250-5_2

14. Thompson, M. M., Lagerstedt, H. B. \& Mehlenbacher, S. A. (1996). Hazelnuts. In J. Janick \& J. N. Moore (Eds.), Fruit Breeding: Vol. 3. Nuts (pp. 125-184). New York: Wiley.

15. Kubitzki, K. (1993). Betulaceae. In K. Kubitzki, J. G. Rohwer, \& V. Bittrich (Eds.), The families and genera of vascular plants: Vol. 2. Flowering Plants. Dicotyledons: Magnoliid, Hamamelid and Caryophyllid Families (pp. 152-157). Berlin, Heidelberg: Springer Verlag.

16. Botta, R., Emanuel, E., Me, G., Sacerdote, S. \& Vallania, R. (1986). Indagine cariologica in alcune specie del genere Corylus. Riv. Ortoflorofrutt. Ital., 70(5), 323-329.

17. Erdoğan, V. (1999). Genetic relationships among hazelnut (Corylus) species. Ph.D. Thesis (Horticulture). Oregon State University, Corralis, OR, USA.

18. Mehlenbacher, S. A., Brown, R. N., Nouhra, E. R., Gokirmak, T., Bassil, N. V., \& Kubisiak, T. L. (2006). A genetic linkage map for hazelnut (Corylus avellana L.) based on RAPD and SSR markers. Genome, 49(2), 122-133.

19. Kasapligil, B. (1968). Chromosome studies in genus Corylus. Scientific reports of the Faculty of Science, Ege University, 59, 3-14.

20. Wetzel, G. (1929). Chromosomen studienbei den Fagales. Botanisches Archiv: Zeitschrift für die gesamte Botanik, 25(3/4), 257-283.

21. Vavilov, N. I. (1926). Tsentry proiskhozhdeniya kulturnykh rasteniy [Centers of cultivated plants origin]. Leningrad: AllUnion Research Institute of Applied Botany and New Crops, GIOA. [in Russian]

22. Masla rastitelnye. Metod opredeleniya zhirnokislotnogo sostava: GOST 30418-96 [Vegetable oils. Method of determination of fatty acid content: State Standart 30418-96] (pp. 110-116). (2001). Moscow: Standard Publishing House. [in Russian]

23. Ma, Q. H., Wang, G. X., Liang, W. J., Chen, X., Liang, L. S., \& Zhao, T. T. (2013). Progress on pollen-stigma compatibility in Corylus (hazelnuts): a review. J. For. Res., 24(3), 397-402. doi: 10.1007/s11676-013-0372-7

24. Grodzinskiy, A. M., Balabushka, V. K., Balabushka, L. V., Kosenko, I. S., \& Parkhomenko, L. I. (1989). Avtorskoe svidetelstvo № 1547733. Sposob poseva semyan drevesnykh rasteniy. [Invention certificate No. 1547733. Method of sowing of woody plant seeds]. Registered in the National registry of inventions of the USSR November 8, 1989. [in Russian]

25. Kosenko, I. S., Balabak, 0. A., Opalko A. I., Tarasenko, H. A., \& Balabak, A. V. (2015). Patent na korysnu model № 98106.
Sposib rozmnozhennia funduka [UA Patent on the useful model No. 98106. Method of hazelnut propagation]. Registered in the National patent registry of Ukraine on useful models 10.04.2015. [in Ukrainian]

\section{Literature}

1. Косенко I. С., Опалко А. І., Балабак 0. А., Шульга С. М. Використання генетичної колекції Corylus spp. НДП «Софіївка» для селекції фундука Corylus domestica Kos. et Opal. Aвтохтонні та інтродуковані рослини : зб. наук. пр. Умань, 2016. Вип. 12. С. 121-136.

2. Hazelnuts, with shell. FAOSTAT Domains Production/Crops: Average. URL: http://faostat3.fao.org/browse/Q/QC/E.

3. Maloshtan L. M., Kalenichenko G. S., Dorovskyy 0. V. (2015). The study of the action of the thick extract from the leaves of Corylus avellana on the vascular tissue permeability. Клінічна фармація. Vol. 19, Iss. 4. P. 26-29. doi: 10.24959/cphj.15.1362

4. Esposito T., Sansone F., Franceschelli S. et al. Hazelnut (Corylus avellana $\mathrm{L}$.) shells extract: phenolic composition, antioxidant effect and cytotoxic activity on human cancer cell lines. Int. J. Mol. Sci. 2017. Vol. 18, Iss. 2. P. 392. doi: 10.3390/ijms18020392

5. Lemmon M. A. Membrane recognition by phospholipid-binding domains. Nat Rev Mol Cell Biol. 2008. Vol. 9, Iss. 2. P. 99-111. doi: $10.1038 / \mathrm{nrm} 2328$

6. Ефременко В. И. Липосомы (получение, свойства, аспекты применения в биологии и медицине). Ставрополь, 1999. 236 с.

7. Angelova-Romova M.,Zlatanov M., Antova G. et al. Phospholipids content and composition of hazelnut and walnut cultivars grown in Bulgaria. Comptes rendus de l'Académie bulgare des Sciences. 2013. Vol. 66, Iss. 12. P. 1689-1694.

8. Corylus. Catalogue of Life: 29th May 2017. Naturalis Biodiversity Center. URL: http://www.catalogueoflife.org/testcol/search/ all/key/Corylus/match/1.

9. Corylus. The Plant List by the Royal Botanic Gardens Kew and Missouri Botanical. URL: http://www.theplantlist.org/tpl1.1/ search?q=Corylus.

10. Woodworth R. H. Cytological studies in the Betulaceae. II. Corylus and Alnus. Botanical Gazette. 1929. Vol. 88, No. 4. P. 383-399.

11. Хромосомные числа цветковых растений / под ред. А. А. Федорова. Ленинград : Наука, 1969. 927 с.

12. Danielsson-Santesson B. Fortsatta Undersökningar av polyploid hassel. Sveriges Pom. Fören. Ersskrift. 1951. Vol. 52. P. 38-48.

13. Molnar T. J. Corylus L. Wild crop relatives: genomic and breeding resources. Forest trees / C. Kole (ed.). Berlin, Heidelberg: Springer, 2011. Vol. 10. P. 15-48. doi: 10.1007/978-3-642-21250-5_2

14. Thompson M. M., Lagerstedt H. B., Mehlenbacher S. A. Hazelnuts. Fruit Breeding. Vol. 3. Nuts / J. Janick, J. N. Moore (eds). New York : Wiley, 1996. P. 125-184.

15. Kubitzki K. Betulaceae. The families and genera of vascular plants. Vol. 2. Flowering Plants. Dicotyledons: Magnoliid, Hamamelid and Caryophyllid Families / K. Kubitzki, J. G. Rohwer, V. Bittrich (eds). Berlin, Heidelberg : Springer Verlag, 1993. P. 152-157.

16. Botta R., Emanuel E., Me G. et al. Indagine cariologica in alcune specie del genere Corylus. Riv. Ortoflorofrutt. Ital. 1986. Vol. 70, No. 5. P. 323-329.

17. Erdoğan V. Genetic relationships among hazelnut (Corylus) species: Ph.D. Thesis (Horticulture) / Oregon State University. Corralis, OR, USA, 1999. $218 \mathrm{p}$.

18. Mehlenbacher S. A., Brown R. N., Nouhra E. R. et al. A genetic linkage map for hazelnut (Corylus avellana L.) based on RAPD and SSR markers. Genome. 2006. Vol. 49, Iss. 2. P. 122-133.

19. Kasapligil B. Chromosome studies in genus Corylus. Scientific reports of the Faculty of Science, Ege University. 1968. Ser. 59. P. 3-14.

20. Wetzel G. Chromosomen studienbei den Fagales. Botanisches Archiv: Zeitschrift für die gesamte Botanik. 1929. Vol. 25, Iss. 3/4. P. 257-283. 
21. Вавилов Н. И. Центры происхождения культурных растений. Ленинград : ВИПБиНК и ГИОА, 1926. 252 с.

22. Масла растительные. Метод определения жирнокислотного состава : ГОСТ 30418-96. [Дата введения 1998-01-01]. Москва : ИПК Издательство стандартов, 2001. С. 110-116. (Межгосударственный стандарт).

23. Ma Q. H., Wang G. X., Liang W. J. et al. (2013). Progress on pollen-stigma compatibility in Corylus (hazelnuts): a review. J. For. Res. Vol. 24, Iss. 3. P. 397-402. doi: 10.1007/s11676013-0372-7
24. А. с. №1547733. Способ посева семян древесных растений / А. М. Гродзинский, В. К. Балабушка, Л. В. Балабушка, И. С. Косенко, Л. И. Пархоменко // Госкомизобретения. Заявка № 4357637 от 4 янв. 1988 г. Зарегистрировано в Гос. реестре изобретений СССР 8 нояб. 1989 г. 2 с.

25. Патент на корисну модель № 98106 . Спосіб розмноження фундука / I. С. Косенко, О. А. Балабак, А. І. Опалко, Г. А. Тарасенко, А. В. Балабак // Заявка № u2014 13707 подана 22.12.2014; зареєстрована у Держ. реєстрі патентів України на корисні моделі 10.04.2015, Бюл. 2015, № 7.4 с.

УдК 631.527: 634.54: 581.6: 582.632.1

Косенко I. C. ${ }^{*}$, 0палко A. I. ${ }^{1{ }^{*}}$, Балабак 0. A. ${ }^{1}$, Опалко 0. А. ${ }^{1}$, Балабак A. B. ${ }^{2}$ Селекція фундука в Національному дендрологічному парку «Софіївка» НАН України. Сортовивчення та охорона прав на сорти рослин. 2017. Т. 13, № 3. С. 245-251. http://dx.doi.org/10.21498/2518-1017.13.3.2017.110706

${ }^{1}$ Національний дендрологічний парк «Софіївка» НАН України, вул. Київська, 12а, м. Умань, Черкаська обл., 20300, Україна *e-mail: ndp.sofievka@gmail.com

уманський національний університет садівництва, вул. Інститутська, 1, м. Умань, Черкаська обл., 20300, Україна, *e-mail:opalko_a@ukr.net

Мета. Оцінити види, гібриди та сорти фундука з генетичної колекції Corylus spp. Національного дендропарку «Софіївка» НАН України за комплексом господарсько-цінних ознак. Зроблено спробу проаналізувати інформацію про Corylus spp. ідентичність, таксономію та описи, поширення та екологічні вимоги видів, можливості використання генетичного потенціалу для створення нових сортів. Методи. Цінність представників колекції Corylus spp. досліджували за допомогою загальноприйнятих методів випробувань. Для узагальнення інформації про філогенетичну реконструкцію роду Corylus L. та фундука було проаналізовано ряд наукових публікацій, запропонованих для обговорення. Вміст олії в ядрах горіхів фундука та склад жирних кис-

лот визначали офіційними методами. Результати. Кращі зразки генетичної колекції фундука були включені в широку програму гібридизації, в тому числі з представниками C. chinensis Franch. Отримано ряд гібридних сіянців, зокрема нових сортів фундука 'Софіївський 1', 'Софіївський 2' та 'Софіївський 15', що характеризуються сферичними або майже сферичними плодами, підвищеною зимосостійкістю та стійкістю проти посухи, а також відсутністю періодичності плодоношення. Висновки. Колекція різновидів, форм, сортів та видів роду Corylus L., створена останніми роками, може бути базою для селекції фундука в Україні.

Ключові слова: селекція, сорт, природний ареал роду, програма гібридизації, горіх, види.

УДК 631.527: 634.54: 581.6: 582.632.1

Косенко И. С. ${ }^{{ }^{*}}$, Опалко А. И. ${ }^{1,2^{*}}$, Балабак А. A. ${ }^{1}$, Опалко 0. А. ${ }^{1}$, Балабак А. В. ${ }^{2}$ Селекция фундука в Национальном дендрологическом парке «Софиевка» НАН Украины // Сортовивчення та охорона прав на сорти рослин. 2017. Т. 13, № 3. С. 245-251. http://dx.doi.org/10.21498/2518-1017.13.3.2017.110706

${ }^{1}$ Национальный дендрологический парк «Софиевка» НАН Украины, ул. Киевская, 12а, г. Умань, Черкасская обл., 20300, Украина, *e-mail:ndp.sofievka@gmail.com

гуманский национальный университет садоводства, ул. Институтская, 1, г. Умань, Черкасская обл., 20300, Украина, *e-mail:opalko_a@ukr.net

Цель. Оценить, виды, гибриды и сорта фундука из генетической коллекции Corylus spp. Национального дендрологического парка «Софиевка» НАН Украины по комплексу хозяйственно-ценных признаков. Сделана попытка проанализировать информацию о Corylus spp. идентичности, таксономии и описании, распространении и экологических требованиях видов, возможности использования генетического потенциала для создания новых сортов. Методы. Ценность представителей коллекции Corylus spp. исследовали с помощью общепринятых методов испытаний. Для обобщения информации о филогенетической реконструкции рода Corylus L. $и$ фундука было проанализировано ряд научных публикаций, предложенных для обсуждения. Содержание масла в ядрах орехов фундука и состав жирных

кислот определяли официальными методами. Результаты. Лучшие образцы генетической коллекции фундука были включены в широкую программу гибридизации, в том числе с представителями C. chinensis Franch. Получен ряд гибридных сеянцев, в частности новые сорта фундука 'Софиевский 1', 'Софиевский 2' и 'Софиевский 15', которые характеризуются сферическими или почти сферическими плодами, повышенной зимостойкостью и засухоустойчивостью, а также отсутствием периодичности плодоношения. Выводы. Коллекция разновидностей, форм, сортов и видов рода Corylus L., созданная в последние годы, может служить базой для селекции фундука в Украине.

Ключевые слова: селекция, сорт, естественный ареал рода, программа гибридизации, орех, виды.

Надійшла / Received 14.07.2017

Погоджено до друку / Accepted 25.08.2017 